See discussions, stats, and author profiles for this publication at: https://www.researchgate.net/publication/328721387

\title{
Hybridization and Its Application in Aquaculture
}

Chapter $\cdot$ November 2018

DOI: 10.1002/9781119127291.ch7

\section{CITATIONS}

4

4 authors, including:

Md. Aminur Rahman

Universiti Putra Malaysia

113 PUBLICATIONS 1,136 CITATIONS

SEE PROFILE

Rafiquzzaman S M

20. Bangabandhu Sheikh Mujibur Rahman Agricultural University 32 PUBLICATIONS 172 CITATIONS

SEE PROFILE

Some of the authors of this publication are also working on these related projects:

RMK11 - Lake Trophic Study, Inventory and Classification View project

Project Dietary supplement of $\mathrm{E}$. faecalis on digestive enzymes... View project
READS

5,620

Fatimah Md Yusoff

Universiti Putra Malaysia, Serdang, Selangor

262 PUBLICATIONS 4,240 CITATIONS

SEE PROFILE 


\title{
Hybridization and Its Application in Aquaculture
}

\author{
M. Aminur Rahman ${ }^{1,2}$, Sang-Go Lee ${ }^{1}$, Fatimah Md. Yusoff ${ }^{2,3}$, and S.M. Rafiquzzaman ${ }^{4}$ \\ ${ }^{1}$ World Fisheries University Pilot Programme, Pukyong National University (PKNU), South Korea \\ ${ }^{2}$ Laboratory of Marine Biotechnology, Institute of Bioscience, Universiti Putra Malaysia \\ ${ }^{3}$ Department of Aquaculture, Faculty of Agriculture, Universiti Putra Malaysia \\ ${ }^{4}$ Department of Fisheries Biology and Aquatic Environment, Bangabandhu Sheikh Mujibur Rahman Agricultural University, \\ Gazipur, Bangladesh
}

\subsection{Introduction}

With global population expansion, the demand for high quality protein, especially from aquatic sources, is rising dramatically. Increased aquaculture production is clearly needed to meet this demand. In the third millennium, because capture fishes are at capacity or showing precipitous declines due to over-fishing, habitat destruction, and increasing population, increase in capture fishes is not anticipated under the global conditions [1].

Development of better fish breeds that can contribute to increased fish production, while ensuring protection of biodiversity and the environment, is seen as one of the key solutions to meet future food demands of the growing world population $[2,3]$. The advent of induced spawning techniques, such as hypophysation (the use of pituitary gland extract to induce ovulation), synthetic hormones, in vitro fertilization technologies, and increased knowledge of reproductive biology, has enabled aquaculturists to induce breeding and domesticate many fish species for aquaculture. As domestication of fish species increases, the possibility of increasing fish production through appropriate genetic improvement methods also increases. Hybridization is considered as one of the simple, inexpensive, and potential tools of such enhancement programs in fishes; it is a useful method for combining the desirable traits of selected species.

The mating of two different species is a process called hybridization, with the offspring known as hybrids. Hybrids can have some characteristics of both parental species. A hybrid with selected or favored characteristics of each parent is one of the goals of animal husbandry. When a hybrid has characteristics superior to both parents, it is said to have hybrid vigor or positive heterosis, which, of course, is the ultimate breeding goal.

Hybridization occurs widely in fishes under natural conditions [4-6], and is observed in fish more commonly than in other vertebrate animal groups $[7,8]$. Several factors have been suggested as contributing to the high incidence of natural hybridization among closely related fish species, including external fertilization, weak behavioral isolating mechanisms, unequal abundance of the two parental species, competition for limited spawning habitat, and decreasing habitat complexity [4, 7]. Hybrid zones are defined 
as areas of narrow regions where genetically distinct populations or species meet, mate, and produce hybrids [9].

Intraspecific hybridization (cross-breeding) is a classical approach for the genetic improvement of livestock animals [10-21]. This method has also shown its potential in aquaculture. Increases by $55 \%$ and $22 \%$ in the growth rate of channel catfish and rainbow trout hybrids, respectively, were achieved using this technique [22, 23]. However, there was no increase in growth rates in Chum Salmon crossbreeds when compared with parental strains [24]. Cross-breeds of different strains of European catfish, Silurus glanis, exhibited higher adaptability under warm water conditions and mixed diet feeding regimes [25].

Gjerde and Refstie [26] investigated the heterosis effect between crosses of five Norwegian strains of Atlantic salmon. They did not find a significant heterosis effect for either growth rate or survival rate. Similarly Friars et al. [27] found no heterosis effect for growth rate of Atlantic salmon fry.

Interspecific hybrids have, thus, attracted attention because they can improve productivity through hybrid vigor, transfer desirable traits, or produce sterile animals [28-33]. Hybridization may also be used to combine other valuable traits, such as better growth and flesh quality, disease resistance, and increased environmental tolerances. In recent years, hybrids of major carps have been successfully produced in public and private hatcheries, and are available for farming, due to high resistance against unfavorable ecological conditions [34, 35].

Many molecular biologists and fish geneticists have realized that the use of inter-specific hybrids in global fisheries production is not well-reported nor examined properly. On the other hand, there have still been some controversies in global acceptance for using interspecific hybrid organisms that have been genetically modified (GMOs) [36-38]. Intraspecific hybrids are GMOs. They are sometimes created through natural means, but represent a combination of the genes of two different "species." This study focuses on the crossing among different genetically distinct species and rearing of hybrids, to understand the potentiality of hybrids in the world's aquaculture production.

\subsection{Inter-specific Hybrids and Their Applications in Aquaculture}

Inter-specific hybridization has long been practiced in various species of fishes to increase growth rate, improve flesh quality, produce sterile animals, increase disease resistance and environmental tolerance, and to improve other quality traits to make fish more profitable (Table 7.1) [25].

The majority of the earlier works on hybridization was conducted for salmonid fishes, but these species did not usually produce hybrids of commercial importance [25]. For this reason, hybrids in these fishes do not draw the attention of fish culturists [39]. Due to the increased expansion of fish farming throughout the world, hybrids produced from inter-specific crosses play a substantial role for global aquaculture production. The increased use of artificial breeding and in vitro fertilization techniques, and increased knowledge of reproductive biology, encourage aquaculturists to produce hybrids in order to improve the quality traits over their pure parental siblings. Some of the important traits and performances that have been improved through hybridization among different species of fishes are evaluated below.

\subsubsection{Improved Growth Performances}

Increased growth rate is the most desirable trait for stock improvement in aquaculture. Growth increase may result from dominant variance [40], or from increasing the number of polymorphic loci in an individual. Increased heterozygosity has been implicated in improved growth in a variety of species, as 
Table 7.1 Summarization of hybrid fishes in global aquaculture production and stock enhancements [25].

Hybrids

\section{Cyprinid fishes}

Rohu $\times$ catla (Labeo rohita $\times$ Catla catla)

Catla $\times$ fringe-lipped peninsular carp

(C. catla $\times$ L. fimbriatus)

Silver carp $\times$ bighead carp

(Hypophthalmichthys

molitrix $\times$ Aristichthys nobilis)

Grass carp $\times$ bighead carp

(Ctenopharyngodon idella $\times$ A. nobilis)

Common carp $\times$ catla (Cyprinus carpio $\times$

C. catla) and common carp $\times$ mrigal

(C. carpio $\times$ Cirrhinus mrigala)

\section{Tilapia fishes}

Nile tilapia $\times$ blue tilapia (Oreochromis niloticus $\times$ O. aureus)

Nile tilapia $\times$ long-finned tilapia

(O. niloticus $\times$ O. macrochir)

Nile tilapia $\times$ Wami tilapia (O. niloticus $\times$ O. hornorum)

Mozambique tilapia $\times$ Nile tilapia

(O. mossambicus $\times$ O. niloticus)

Mozambique tilapia $\times$ Wami tilapia

(O. mossambicus $\times$ O. hornorum)

\section{Salmon and Trout}

Atlantic salmon $\times$ brown trout (Salmo salar $\times$ S. trutta)

Brown trout $\times$ brook trout (Salmo trutta $\times$ Salvelinus fontinalis)

Rainbow trout $\times$ char trout (Oncorhynchus mykiss $\times$ Salvelinus sp.)

Lake trout $\times$ brook trout (Salvelinus namaycush $\times$ S. fontinalis)

Chum salmon $\times$ Chinook salmon (O. keta $\times$ O. tshawytscha)

Hybridization among the Pacific salmons (Oncorhynchus spp.)
Characteristics, effects, and advantages

References

Hybrid is hardy and combines first growth of catla with desirable small head shape of rohu.

Hybrid has desirable head and body shape, improved dressing percentage, and growth performances similar to those exhibited by catla

Hybrids are fertile and exhibits positive heterosis in growth. Pure lines may have disappeared because of the fertility of hybrids. Food and feeding strategy is intermediate to parental species.

Hybrids are generally sterile and functional triploids with higher growth rates.

Hybrids are usually functional triploids and sterile, having higher growth and survival in monoculture practices and with good seinability

Hybrids of some strains yield all-male offspring with superior growth. Some hybrids are fertile with increased cold and salinity tolerance. Reciprocal cross gives $50 \%$ males and females.

Hybrid yields predominately male offspring, but strain of Nile tilapia is important for good fry production.

Hybrid yields predominately male offspring with some strains producing red-skinned fish with salt tolerance.

Recognized as Taiwan red with higher salinity tolerance; progeny of these hybrids display a variety of different skin colors.

Hybrid yields predominately male offspring and are fertile. Certain strains produce Florida red tilapia with salinity tolerance and good growth.

[61], [65], [66]

[46], [59], [60], [61]

Triploid hybrid exhibits the higher growth and survival to a comparable level to Atlantic salmon, but offspring becomes sterile.

Hybrid known as tiger trout is sterile, with low early survival, but grows well in later stages.

Hybrid shows increased disease resistance to salmonid viruses.

Hybrid commonly recognized as splake, and is fertile, fast growing, and tolerant of acid water.

Triploid hybrids have early seawater tolerances.

Majority of the diploid hybrids are not useful for aquaculture, but have potential for disease resistance, sterility, and early seawater tolerance when the diploid hybrids are made triploid. These are also useful for production of all-female using denatured sperm and rediploidized eggs. 
well as other desirable characteristics such as developmental compatibility [41], food conversion efficiency, and oxygen metabolism $[42,43]$.

A hybrid between white bass (Morone chrysops) and the striped bass (M. saxatilis), called sunshine bass, exhibits faster growth and has many more good culture characteristics than either of the parents under captive culture systems [44]. Crosses of the black crappie $\times$ white crappie (Pomoxis nigromaculatus $\times P$. annularis), stocked in small ponds and impoundments [45]; silver carp $\times$ bighead carp (Hypophthalmichthys molitrix $\times$ Aristichthys nobilis) [46] in polyculture systems; and catfish hybrids between the African catfish (Clarias gariepinus) and the Vundu (Heterosneustes longifilis or $H$. bisorsalis) in intensive concrete tanks $[47,48]$, were reported to grow faster (positive heterosis) than conspecific parents.

Improved growth performances were also obtained from crosses of mrigal (Cirrhinus mrigala) and catla (Catla catla), and common carp (Cyprinus carpio) with rohu (Labeo rohita) in pond culture systems in India [49]. Intergeneric hybrids between catla (Catla catla) and fimbriatus (Labeo fimbriatus) were observed to combine desirable qualities, such as the small head of the fimbriatus and the deep body of the catla, and exhibited heterosis in terms of meat yield with higher flesh content than either of the parents [50].

Hybrids between tambaqui (Clossoma macropomum) and pacu (Piaractus brachypoma) in Brazil and Venezuela raceways and ponds grew faster than either parent [51]. Crosses of the green sunfish (Lepomis cyanellus) with bluegill (L. macrochirus) [52, 53], and crosses of the gilthead sea bream (Sparus auratus) with red sea bream (Pagrus major), also had positive heterosis in growth and other culture characteristics [54]. Several hybrids have been produced in the Mediterranean, with the cross between red sea bream and common dentex (Dentex dentex) being especially fast growing in cage culture management [55].

\subsubsection{Production of Sterile Animals}

Hybridization often results in offspring that are either sterile or have reduced reproductive capacity. Production of sterile animals may be advantageous to diminish unwanted reproduction, or to improve growth rate and avoid energy loss due to prolific breeding. Examination of species karyotype is a good general indication of whether or not hybridization will result in offspring that are sterile $[25,39]$. Karyotypes describe the chromosome count from the nucleus in a eukaryotic cell of an organism, and what these chromosomes look like under a light microscope, where attention is usually paid to their length, the position of the centromeres, banding pattern, differences between the sex chromosomes, and any other physical characteristics [56].

Natural hybrids produced from the cross between grass carp (Ctenopharyngodon idella) and bighead carp (Aristicthys nobilis) are functionally triploids, generally sterile, but with a small proportion being diploid and fertile [57]. Hybrids between Indian major carps are generally fertile because of similar chromosome numbers $(2 n=50)$. Indian major carps crossed with Common Carp $(4 n=102)$ results in hybrids that are sterile because they are functionally triploid $[34,49]$. However, crosses of some sturgeon species with different chromosome numbers, as well as most tilapia crosses, produce fertile offspring [58-61].

The cross between the black crappie (Pomoxis nigromaculatus) and white crappie (P. annularis) exhibits positive heterosis, and is often recommended for stocking in small impoundments, because of reduced fertility of the $\mathrm{F}_{2}$ generation that would prevent overpopulation [45]. The sunshine bass is generally sterile but, apparently, an undetermined percentage of these hybrids are capable of reproduction, as evidenced by hybrid mating and backcrossing [62]. The red sea bream $\times$ gilthead sea bream cross also produces sterile hybrids, and this may be an important quality in marine aquaculture due 
to improved growth rate and good overall performance in cage culture [54]. The tiger trout, a hybrid between brown trout (Salmo trutta) and brook trout (Salvelinus fontinalis) is sterile, with poor early survival, but good growth rate, and therefore is useful for stocking areas where reproduction is very limited [63].

\subsubsection{Manipulation of Sex Ratio}

Production of monosex populations in fish is often preferable for aquaculture development. This preference may be due to growth differences between sexes (e.g., male tilapia grow faster than females, whereas female salmonids and sparids grow better than males). A specific sex chromosome (XX chromosomes for female and XY for male individuals) may produce a valuable product and monosex populations, and help reduce unwanted reproduction [39].

Hybridization between some species of tilapias, such as the Nile tilapia (Oreochromis niloticus) and the blue tilapia (O. aureus), results in the production of predominantly male offspring, and reduces unwanted reproduction in grow-out pond culture management [64]. This cross produces predominantly males, because of different sex-determining mechanisms in the two species, and the hybrid males have superior growth over pure parental species. Nile tilapia has the XX, XY system, with the male being heterogametic, whereas blue tilapia has the $\mathrm{ZZ}, \mathrm{ZW}$, with the heterogametic genotype being female $[61,65,66]$.

Similarly, crosses between Nile tilapia (O. niloticus) and Wami tilapia (O. honorum), Nile tilapia and long-finned tilapia (O. macrochir), and Mozambique tilapia (O. mossambicus) and Wami tilapia produce hybrid offspring that are predominantly male, with excellent growth and production [61]. Hybridization between striped bass (Morone saxatilis) and yellow bass (M. mississipiensis) produces 100\% females, with excellent survival and growth in culture systems [67].

\subsubsection{Overall Improvement}

The principal aim of hybridization is to combine desirable traits from different species to increase the overall production or marketability of a cultured species. The major hybrid catfish cultured in Thailand is a cross between African (Clarias gariepinus) and Thai (C. macrocephalus) catfish, which combines the fast growth rate of the African catfish with the desirable flesh characters of the Thai catfish [48]. The overall product is improved, and the flesh is still acceptable to Thai consumers, although it does not grow as fast as the pure African catfish.

The rohu $\times$ catla hybrid grows almost as fast as pure catla, but has the small head of the rohu and is, therefore, useful in Indian aquaculture [34]. Catla $\times$ fringed-lipped peninsula carp (Labeo fimbriatus) were reported to have small heads of the fringed-lipped peninsula carp, and deep body and nearly equal growth rate to the catla; the dressing percentage also improved in this hybrid [50]. The sunshine bass hybrid (white bass $\times$ striped bass) has a suite of advantageous traits, including good osmoregulation, high thermal tolerance, resistance to stress and disease, high survival in culture and modified water-bodies, and ability to utilize soy beans as a protein source $[44,55]$. The overall growth performances of hybrids (C. catla $\times$ L. rohita) fed on wheat bran was consistently higher, followed by rice broken, and blood meal [35].

Among the cultivatable hybrids, red tilapia is more desirable than darker skinned tilapia in Cuba, Venezuela, Thailand, Europe, and the United States. Most red tilapia are descended from the Nile $\times$ blue tilapia cross [66], but red tilapia also result from the cross of Wami tilapia (O. urolepishormorum) $\times$ Mozambique tilapia [60]. It has been reported that red tilapia from Nile tilapia $\times$ Mozambique tilapia, and Nile tilapia $\mathrm{x}$ Wami tilapia, are being farmed in central Thailand to Lao PDR for aquaculture purposes (Welcomme, personal communication). The latter cross is also salttolerant and used for coastal aquaculture in 
parts of Southeast Asia [68]. Stability of the skin coloration is often a problem in successive generations, and studies have been undertaken to understand the genetic mechanisms of color inheritance $[69,70]$.

Hybrids between different species of North American catfish have been researched for more than 30 years. Among the interspecific catfish hybrids, crosses between channel catfish (Ictalurus punctatus) and blue catfish (I. furcatus) exhibit good culture characters of the channel catfish, with the ease of harvesting characteristics of the blue catfish, such as better angling and increased seinability [71]. Once breeding problems are worked out, these hybrids may be useful in culture, as they show heterosis for growth rate and are superior to channel catfish in low oxygen tolerance, disease resistance uniformity in body shape, angling vulnerability, seinability, and dress-out percentage [71].

The hybrid produced from the crosses between the muskellunge (Esox masquinongy) and the pike (E. luscious) is sterile and well-adapted to intensive culture systems. However, the hybrid has similar sport fish characteristics to the pure parental muskellunge, but higher protein requirements than both parental species [72].

\subsubsection{Disease Resistance and Environmental Tolerances}

Hybridization may be used to improve disease resistance by breeding a higher resistant species with a less resistant one. Dorson et al. [73] reported that crosses of coho salmon (Oncorhynchus kisutch) with other species, such as rainbow trout, had increased disease resistance to a variety of salmonid viruses, but other culture characteristics were poor. Viability was increased when hybridization was followed with triploidization, and Dorson et al. [73] stated that the rainbow trout $(O$. mykiss $) \times$ char (Salvelinus spp.) triploid hybrids had increased resistance to several pathogenic salmonid viruses and early sea water tolerance.
Hybrids may have increased environmental tolerances when one parental species has a wide range of tolerance (e.g., euryhaline species), a specific tolerance (cold tolerance species), or because of increased heterozygosity sometimes being associated with a broad niche $[74,75]$. Mozambique tilapia and Wami tilapia can reproduce in saline waters, but the Nile tilapia has improved culture performance in many aquaculture systems. Hybridization between Mozambique and Nile tilapias yields a red tilapia with salinity tolerance [76]. Hybrids between Mozambique and Wami tilapia, called the Florida Red strains, have high growth rates and can reproduce in salinities of 19 ppt [59]. Crosses between Nile tilapia and blue tilapia also resulted in progeny with good salinity tolerances $[61,65]$. Hybrids also may be used to exploit degraded aquatic environments.

Lakes affected by acid rain may not be suitable for native salmonids, but splake, a hybrid between lake trout (Salvelinus namaycush) and brook trout (S. fontinalis) can tolerate the reduced pH levels of 4.9-5.4 of the acid lakes of Ontario. Lake trout reproduce successfully only in waters with $\mathrm{pH}$ values above 5.5 [77]. The splake has also been shown to have higher survival and growth than both brook and lake trout in lakes with $\mathrm{pH}$ in the range of 5.5-7.2 [78].

\subsubsection{Hybrid Polyploidization}

Hybridization combined with chromosome manipulation may increase the viability and developmental stability of hybrid fishes during early life history stages [79]. Polyploid hybrid salmon appear to be better suited for a variety of culture situations than either polyploid or hybrid salmon are on their own. Although many diploid salmonid hybrids are not used for culture, triploidization of the hybrids may confer increased viability, growth, and survival [80].

Triploidization of Atlantic salmon (Salmo salar $) \times$ brown trout $(S$. trutta $)$ hybrids increased survival and growth rate to a level comparable to Atlantic salmon [81]. 
General disease resistance was improved by triploidizing the cross between rainbow trout and char; rainbow trout and coho salmon triploid hybrids had increased resistance to infectious disease, but the latter hybrids grew more slowly [73]. Triploid Pacific salmon hybrids between chum salmon (Oncorynchus keta) and Chinook salmon (O. tshawytscha) have earlier seawater acclimatization times [82].

\subsubsection{Experimental Hybridization}

Laboratory hybridization experiments have been utilized extensively to confirm the probable hybrid nature of certain individuals, by demonstrating that two taxa will interbreed when provided with the opportunity to do so, or that gametes from two taxa can be artificially cross-fertilized. Hybrids produced from appropriate cross-fertilization techniques among commercially important fish species have been tested for their growth performance, viability, and fertility. A hybrid recently produced experimentally between sheim (Acanthopagus latus) and sobiaty (Sparidentex hasta) in Kuwait appears to have good growth, flesh quality, and is fertile (Khaled Al-AbdulElah Kuwait Institute of Scientific Research, personal communication).

Hybrids resulting from crossing several sunfish species have been used for the past three decades to improve farm pond fishing. The most desirable hybrids result from crossing the female green sunfish (Lepomis cyanellus) with males from one of three other species. These include the bluegill (L. macrochirus), the redear, or shellcracker (L. microlophus), and the warmouth, or goggleye (L. gulosus). The most commonly used hybrid in the southeast United States is the male bluegill $(B G) \times$ female green sunfish $(\mathrm{GS})$ cross. This BG $\times$ GS hybrid has the most desirable set of characteristics, which means that the hybrids can outperform their parental species in one or more ways.

Rapid and superior growth is one way hybrid sunfish exhibit hybrid vigor. Experimental hybrids between dusky grouper (E. margina$t u s)$ and the white grouper ( $E$. aeneus) were evaluated, but all the hybrids died within 10 days post-hatching [83]. The camouflage grouper (Epinephelus polyphekadion) is more resistant to environmental stress and disease than the marbled grouper (E. fuscoguttatus). Experimental hybrids (marbled grouper $x$ camouflage grouper) exhibited faster growth performances and increased conversion efficiency [84]. A hybrid between the beluga (Huso huso) and Russian sturgeons (Acipenser guldenstati) was evaluated, and appeared to have a wide salinity tolerance to both fresh and seawater, as well as good growth rate [85]. These hybrids are now being considered for culture in Russia and Iran (Shilat, Iranian Fisheries Company, personal communication).

Two loach (Misgumus spp.) are cultured both for food and for ceremonial purposes by Buddhists in Korea [86] - the mud loach (M. mizolepis) and the cyprinid loach (M. anguillicaudutus). The mud loach grows to a larger size, has a faster growth rate, and is more resistant to diseases, while the cyprinid loach has a more desirable body color. These two species of loach were hybridized to combine the fast growth and large size of the mud loach with the desirable body color of the cyprinid loach. Fertilization, hatching, survival, and karyology of the hybrids were very similar to the parents [87]. These hybrids are now being cultured commercially, and continued studies are planned to combine other desirable characteristics of the hybrids and their fertility.

Hybrids produced using the eggs of Asian catfish (Clarias batrachus) and African catfish (C. gariepinus) perform as well as either parental control during the alevin stage, and better in the fry and advanced fry stages, while the reciprocal hybrids are inferior in all performance traits. During the different experiments, this hybrid group showed the highest survival from post-larval stage to market size fish [88, 89]. Growth performance was always better than maternal control and, in some cases, better than or close to paternal control. Preliminary observations of organoleptic testing revealed that the hybrid showed superior taste performance, 
compared with parental groups [88]. Further research is needed to examine other desirable traits of the hybrids and their sterility.

Hybridization between giant catfish (Pangasiodon gigas) and giant pangus (Pangasius sanitwonsei) are now being practiced in Thailand (Pongthana, National Aquaculture Genetics Research Institute, Thailand, personal communication). Both of these catfishes are extraordinarily large, reaching $3 \mathrm{~m}$ and $300 \mathrm{~kg}$, with the giant catfish considered as an endangered species whose trade is restricted under the Convention on International Trade in Endangered Species of Wild Flora and Fauna. Hybrids between these two catfish species show good growth performance, and should be used to reduce pressure on the giant catfish, so as not to endanger it through excessive catch of brood fish from the wild, or through genetic introgression of the two parental species $[25,90]$.

Due to the wide geographical distribution of yellow bass (Morone mississippiensis), hybridization tests with striped bass, and comparisons with the sunshine bass have been conducted. The yellow bass hybrid exhibited $65 \%$ survival to harvest, compared with $45 \%$ for the sunshine bass, but poorer growth rate and condition factor when raised in tanks continuously supplied with pond water [67]. Further research has been undertaken to explore the possibility of combining other desirable traits in the above hybrid progeny.

\subsubsection{Unplanned/Accidental Hybridization}

Unplanned and accidental hybridization in hatchery stocks may cause a genetic deterioration in aquaculture production and open water fisheries. During the production of Indian major carp seeds, different species often are induced to spawn in a common spawning tank, thus providing the opportunity for unintentional hybridization [91]. Silver carp (Hypophthalmichthys molitrix) and bighead carp (Aristichthys nobilis) are sometimes hybridized inadvertently, because of their similar appearance, and because of the shortage of "the correct" species at spawning time, due to differences in maturation times between males and females. This hybridization often results in a fish that does not feed efficiently, as its gill rakers are intermediate in shape between those of the silver carp (which eats phytoplankton) and those of the bighead carp (which consumes zooplankton).

There is much anecdotal evidence of genetic deterioration of carp hatchery stocks in Bangladesh, through inbreeding, negative selection, and hybridization [92]. Stocks of exotic (i.e., non-indigenous) carps are particularly vulnerable to such degradation, given that the opportunities to go back to wild populations for brood stock replenishment are very limited. Furthermore, anecdotal evidence suggests that hybridization between silver carp and bighead carp is common, at least partly due to a shortage of mature bighead carp males toward the end of the breeding season. Reported aquaculture production of the silver carp in Bangladesh in 2001 was 130,000 tons, or $21.7 \%$ of freshwater aquaculture production [93], while there was no reported production figure for bighead carp. Bighead carp brood stock are present in many hatcheries so, presumably, aquaculture production of bighead carp is present, but not high enough to be reported separately.

Hybridization between silver carp has also been reported to occur fairly frequently in commercial aquaculture hatcheries in Bangladesh. The consequences of hybridization for brood stock purity have recently been investigated. Allelic variation at three microsatellite DNA loci isolated from silver carp routinely distinguished between silver carp and bighead carp. These markers were used in the analysis of samples collected from hatcheries in different regions of Bangladesh. Of 422 hatchery broodstock that were morphologically identified as silver carp, $8.3 \%$ had bighead allele(s) at one or more of the three microsatellite loci, while $23.3 \%$ of the 236 fish morphologically identified as bighead carp had silver carp allele(s) at one or 
more loci. The results suggested that, while some of these fish might be $F_{1}$ hybrids, others had more complex genotypes, suggesting further generations of hybridization, or introgression between the species in hatcheries, with potentially damaging consequences for the integrity of these stocks and their performance in aquaculture [94].

Interspecific hybridization in some carp species has recently been reported in Bangladesh [93]. Either out of scientific interest, or shortage of adequate hatchery populations (i.e., brood stock), introgressed hybrids are being produced intentionally or unintentionally by private hatchery operators, and sold to hatchery and nursery owners. These hybrids are being ultimately stocked, knowingly or unknowingly, either in grow-out ponds, or in open water bodies like floodplains under the government's massive carp seed stocking program. There is widespread concern that mass stocking of such hybrids in the floodplains and other related open water might cause a serious genetic introgression problem, which could adversely affect aquaculture and inland open water fish production. There is every possibility of segregation of genes, with the result that some of the fish carrying the introgressed genes could not be easily distinguished from the pure species [92].

Hybrid introgression in major carp species is very likely to have negative consequences, as a result of loss of distinct feeding strategies of the pure species, which are the basis of successful polyculture systems [95]. If the introgressed hybrids reproduce in natural water bodies, or are used as broodstock in hatcheries, they will not be true breeders; therefore, collection of carp seed from the pure species/strains will be difficult.

Hybridization with wild fish is especially prevalent in tilapia ponds connected to natural water bodies that contain indigenous or feral tilapia populations. Such uncontrolled and unintentional hybridization could undermine the performance of cultured stocks, and make future use of the contaminated stocks as broodstock questionable. For example, wild three-spotted tilapia (Oreochromis andersoni) invaded Nile tilapia ponds in Mozambique, and produced hybrid tilapia that was less marketable than pure Nile tilapia. Inadvertent hybridization at a Chinook salmon hatchery was suggested as the probable explanation for the appearance of Chinook $\times$ Coho salmon hybrids in a California stream [96]. The level of unintentional or accidental hybridization has important considerations of aquatic biodiversity, and will influence risk assessment on the use of hybrid fishes in aquaculture.

\subsection{Discussion}

A number of hybridization studies in fishes have been reported $[25,55]$ but certainly not all of the hybrids are contributing to commercial aquaculture production. However, the contributions that hybrid fishes make to global aquaculture production are underestimated. Approximately $80 \%$ of Thai catfish production is from hybrids, and there is a growing concern that these hybrids may be impacting native catfish [90]. The tilapia hybrids in Israel are the main tilapia produced, but the 6,691 mt reported were not identified as hybrid [54]. Production of 4,257 mt of hybrid striped bass was reported from the United States, but production of no other fishes was reported, in spite of the fact that red tilapia and other tilapia hybrids are being produced and sold in Florida [25].

Accurate identification of hybrids is important, not only for sustainable aquaculture development, but also to allow for a better understanding of biodiversity and conservation issues. It would be unfortunate to experience widespread loss of pure species in aquaculture, as happened with tilapia, as a result of widespread loss of pure species and subsequent hybridization [97]. It would be a significant cause for concern if hybrid Thai catfish or hybrid Venezuelan characids poses more of a threat to local species than the pure species. The following points need to be addressed to overcome the above situations, 
as well as to understand the role of hybrids in global aquaculture production [25, 39].

1) Good broodstock management needs to be promoted to avoid inbreeding and interbreeding problems.

2) Species and traits relevant to low-input systems need to be prioritized for genetic enhancement, through proper hybridization programs that better address food security issues.

3) Genetic stock improvement through inter-generic or inter-specific hybridization of cultured fish species should be initiated under well-designed breeding plans at research institutes and lead central hatcheries, under the guidance of fish breeding specialists/biologists.

4) Data on parental origins and stock identity should be recorded for each hybrid. When crosses are made, the female species should be listed first; random crosses in regards to sex of each parent should also be identified.

5) As much information as possible should be made available concerning the hybrid. Necessary information includes the stock and sex of each parental species, a comparative evaluation of the reciprocal crosses including a basic description of culture facility of environment, and an assessment of the fertility of the hybrids [25].

6) Consideration should be given to establishing a recognizable name for established hybrids and those that appear to have good potential for aquaculture and fisheries [25]. The bester and sunshine bass are examples of two accepted names of interspecific hybrids that signify specific hybrids. A number of researchers working on the hybridization of sparids in the Mediterranean have adopted an informal nomenclature, where the cross between the genera Dentex and Pagrus was regarded as "dentagrus," while the reciprocal cross was named as "pantex" [55].

7) In order to maintain genetic integrity, proper care needs to be undertaken so that the hybrids should not be intermingled and do backcross with their parental siblings [33, 98-100].

8) Many private hatchery operators hybridize fish without knowledge of breeding biology and genetics that may cause deterioration of hatchery populations. Therefore, governments should immediately ban the unplanned/intentional hybridization practices being carried out by the hatchery operators and fish seed multiplication farms.

9) Linkages should be established among the general public, organizations, scientists, industry, and governments, to address hybridization issues and to support the development of practical regulation and sound policy.

10) Dissemination of genetically improved aquatic organisms for aquaculture should only be carried out within the framework of adequate regulations and policy.

The management and conservation issues associated with hybridization and introgression in aquatic species are experiencing a renewed interest, based in part on scholarly treatments of the subject [101], and in part because of controversies and difficulties associated with legal mandates such as the Endangered Species Act. In the half century since Hubbs's [4] seminal synthesis on his work with interspecific hybrids, our view of hybridization has drifted away from doctrines that considered it a rare "mistake," toward a more evolutionary perspective that considers it a more common and, occasionally, constructive process. We hope this information serves as a springboard toward more scientific endeavors to understand hybridization as an evolutionarily important phenomenon, and an important living resource management issue, rather than an idle curiosity in nature.

\subsection{Conclusion}

It should be concluded that hybridization is not only a preferred method of genetic improvement, but also a potential tool for 
stock improvement through transmitting desirable traits to the inferior parents. Appropriate evaluation of hybridization depends solely on the genetic structure, crossing patterns, gamete compatibility, and gene flow patterns of the parental species. Practical knowledge on the genetic constitution of brood fishes, including the maintenance of true parental species and avoidance of inbreeding, inadvertent hybridization, or backcrossing, is very crucial before initiating

\section{References}

1 Dunham, R.A., Majumdar, K., Hallerman, E., Bartley, D.M. et al. (2001). Review of the status of aquaculture genetics. In: Subasinghe, R.P., Bueno, P., Phillips, M.J., Hough, C., McGladdery, S.E. and Arthur, J.R. (eds.). Aquaculture in the Third Millenium. Technical Proceedings of the Conference on Aquaculture in the Third Millennium, Bangkok, Thailand, 20-25 February 2000. NACA, Bangkok, Thailand and FAO, Rome, Italy, pp. 129-157.

2 Gupta, M.V. and Acosta, B.O. (2001a). Development of global partnerships for fish genetics research - a success story. Paper presented at the Technical Workshop on Methodologies, Organization and Management of Global Partnership Programmes, 9-10 October 2001, Rome, Italy.

3 Gupta, M.V. and Acosta, B.O. (2001b). Networking in aquaculture genetics research. In: M.V. Gupta and B.O. Acosta (eds.). Fish genetics research in member countries and institutions at the International Network on Genetics in Aquaculture. ICLARM Conference Proceedings, 64, pp.1-5.

4 Hubbs, C.L. (1955). Hybridization between fish species in nature. Systematic Zoology 4, 1-20.

5 Schwartz, F.J. (1972). World literature to fish hybrids, with an analysis by family, species and hybrid. Gulf Coast Research Lab. Mus., No. 3. hybridization experiments. It cannot be ignored that some non-generic factors, such as weather conditions, culture systems, seasons, and stresses associated with selecting, collecting, handling, breeding, and rearing of broodstock and progeny, may influence hybridization success to a greater extent. Further studies are also required for largescale production of fish hybrids that can be utilized for species conservation and commercial aquaculture.

6 Schwartz, F.J. (1981). World literature to fish hybrids, with an analysis by family, species and hybrid. Supplement 1.

Technical Report NMFS SSRF-750. U.S. Department Commerce, National Oceanic and Atmospheric Administration, National Marine Fisheries Service.

7 Campton, D.E. (1987). Natural hybridization and introgression in fishes: Methods of detection and genetic interpretations. In: Ryman N. and F. Utter (eds.), Population Genetics and Fishery Management. University of Washington Press, Seattle, WA, USA, pp: 161-192.

8 Allendorf, F.W. and Waples, R.S. (1996). Conservation and Genetics of Salmonid Fishes. In: Avise, J.C. and J.L. Hamrick (eds.). Conservation Genetics: Case Histories from Nature. Springer, New York, USA, pp: 238-280.

9 Barton, N.H. and Hewitt, G.M. (1985). Analysis of hybrid zones. Annual Review of Ecology and Systematics 16, 113-148.

10 Faruque, S., Husain, S.S., Rahman, M.M., Roy, B.K., Islam M.N. and Islam, M.S. (2002). A study on the reproductive performance of Does in different genetic groups under village condition. Journal of Biological Sciences 2, 325-328.

11 Das, P.K., Ali, S.Z., Islam, A.B.M.M. and Roy, B.K. (2003). A comparative study of productive and reproductive performance and estimates of heritability for economic traits in different genetic groups of cattle 
available at Baghabarighat milk pocket area of Bangladesh. Journal of Biological Science 3, 726-740.

12 Mohammed, M.D., Abdalsalam, Y.I., Kheir, A.R.M., Jin-Yu, W. and Hussein, M.H. (2005). Growth performance of indigenous $\mathrm{X}$ exotic crosses of chicken and evaluation of general and specific combining ability under Sudan condition. International Journal of Poultry Science 4, 468-471.

13 Askari-Hemmat, H. (2006). A year-by-year event scheduled simulation approach to the design of meat sheep crossbreeding systems. Pakistan Journal of Biological Sciences 9, 2189-2197.

14 Musa, H.H., Chen, G.H., Cheng, J.H., Li, B.C. and Mekki, D.M. (2006). Study on carcass characteristics of chicken breeds raised under intensive condition.

International Journal of Poultry Science 5 , 530-533.

15 Mekky, S.S., Galal, A. Zaky, H.I. and Zein-El-Dein, A. (2008). Diallel crossing analysis for body weight and egg production traits of two native Egyptian and two exotic chicken breeds.

International Journal of Poultry Science 7, 64-71.

16 Mirzaei, H.R., Verbyla, A.P. Deland, M.P.B. and Pitchford, W.S. (2009). Describing variation in carcass quality traits of crossbred cattle. Pakistan Journal of Biological Sciences 12, 222-230.

17 Ajayi, F.O. (2010). Nigerian indigenous chicken: A valuable genetic resource for meat and egg production. Asian Journal of Poultry Science 4, 164-172.

18 Adebambo, A.O., Adeleke, M.A. Whetto, M., Peters, S.O. et al. (2010). Combining abilities of carcass traits among pure and crossbred meat type chickens. International Journal of Poultry Science 9, 777-783.

19 Bekele, F., Adnoy, T., Gjoen, H.M., Kathle, J. and Abebe, G. (2010). Production performance of dual purpose crosses of two indigenous with two exotic chicken breeds in sub-tropical environment. International Journal of Poultry Science $\mathbf{9}$, 702-710.
20 Razuki, W.M. and Al-Shaheen, S.A. (2011). Use of full diallel cross to estimate crossbreeding effects in laying chickens International Journal of Poultry Science 10, 197-204.

21 Farahvash, T., Shodja, J,. Rafat A. and Keshtkaran, A. (2011). The effect of bilateral crossbreeding between arkhamerino and ghezel sheep on the quality of wool of their $\mathrm{F}_{1}$ crosses. Asian Journal of Animal and Veterinary Advances 6, 397-400.

22 Dunham, R.A. and Smitherman, R.O. (1983). Crossbreeding channel catfish for improvement of body weight in earthen ponds. Growth 47, 97-103.

23 Dunham, R.A. (1996a). Contribution of genetically improved aquatic organisms to global food security. Proceedings of the International Conference on Sustainable Contribution of Fisheries to Food Security. Government of Japan and FAO, Rome, pp: 1-150.

24 Dunham, R.A. (1996b). Results of early pond-based studies of risk assessment regarding aquatic GMOs. Proceedings of the 126th Annual Meeting of the American Fisheries Society, Dearborn, MI, USA, August 25-29, 1996.

25 Bartley, D.M., Rana, K. and Immink, A.J. (2001). The use of inter-specific hybrids in aquaculture and fisheries. Reviews in Fish Biology and Fisheries 10, 325-337.

26 Gjerde, B. and Refstie, T. (1984). Complete diallele cross between five strains of Atlantic salmon. Livestock Production Science 11, 207-226.

27 Friars, G.W., Bailey, J.K. and Saunders, R.L. (1979). Considerations of a method of analysing diallel crosses of Atlantic salmon. Canadian Journal of Genetics and Cytology 21, 121-128.

28 Chevassus, B. (1983). Hybridization in fish. Aquaculture 33, 245-262.

29 Hedgecock, D. (1987). Interspecific hybridization of economically important crustaceans. Proceedings of the World Symposium on Selection, Hybridization and Genetic Engineering. Aquaculture, II, 
H. Heenemann GmbH, May 27-30, 1986, Berlin, pp: 61-69.

30 Longwell, A.C. (1987). Critical review of methodology and potential for interspecific hybridization. In: Tiews, K. (ed.). Proceedings, World Symposium on Selection, Hybridization and Genetic Engineering in Aquaculture, Vol. 2. H. Heenemann GmbH, Berlin, pp: 3-27.

31 Menzel, W. (1987). Hybridization of oysters and clams. In: Tiews, K. (ed.), Proceedings World Symposium on Selection, Hybridization and Genetic Engineering in Aquaculture, Vol. 2. H. Heenemann GmbH, Berlin, pp: 47-59.

32 Rahman, M.A., Uehara, T. and Aslan, L.M. (2000). Comparative viability and growth of hybrids between two sympatric species of sea urchins (genus Echinometra) in Okinawa. Aquaculture 183, 45-56.

33 Rahman, M.A., Uehara, T. and Lawrence, J.M. (2005). Growth and heterosis of hybrids of two closely related species of Pacific sea urchins (Genus Echinometra) in Okinawa. Aquaculture 245, 121-133.

34 Reddy P.V.G.K. (2000). Genetic Ressources of Indian Major Carps. FAO Fisheries Technical Paper No. 387, FAO, Rome, Italy, $76 \mathrm{pp}$.

35 Um-E-Kalsoom, Salim, M., Shahzadi, T. and Barlas, A. (2009). Growth performance and feed conversion ratio (FCR) in hybrid fish (Catla catla $x$ Labeo rohita) fed on wheat bran, rice broken and blood meal. Pakistan Veterinary Journal 29, 55-58.

36 UNEP (1994). Convention on Biological Diversity. United Nations Environment Programme, Nairobi, Kenya.

37 Bartley, D.M. and Hallerman, E.M. (1995). Global prospective on the utilization of genetically modified organisms in aquaculture and fisheries. Aquaculture 137, 1-7.

38 Hallerman E.M. and Kapuscinsky A.R. (1995). Incorporating risk assessment and risk management into public policies on genetically modified finfish and shellfish. Aquaculture 137, 9-17.
39 Rahman, M.A., Arshad, A., Marimuthu, K., Ara, R. and Amin, S.M.N. (2013). InterSpecific Hybridization and its potential for aquaculture of fin fishes. Asian Journal of Animal and Veterinary Advances 8(2): 139-153.

40 Tave, D. (1986). Genetics for Fish Hatchery Managers. AVI Publishing Co. Inc. Westport Connecticut, 299 pp.

41 Leary R.F., Allendorf F.W. and Knudsen K.L. (1983). Developmental stability and enzyme heterozygosity in rainbow trout. Nature 301, 71-73.

42 Danzmann, R.G., Ferguson, M.M. and Allendorf, F.W. (1985). Does enzyme heterozygocity influence developmental rate in rainbow trout? Heredity $\mathbf{5 6}$, 417-425.

43 Koehn, R.K. and Gaffney, P.M. (1984). Genetic heterozygocity and growth rate in Mytils edulis. Marine Biology 82, 1-7.

44 Smith, T.I.J. (1988). Aquaculture of striped bass and its hybrids in North America. Aquaculture Magazine, 14, 40-49.

45 Hooe M.L., Buck D.H. and Wahl D.H. (1994). Growth, survival, and recruitment of hybrid crappies stocked in small impoundments. North American Journal of Fisheries Management 14, 137-142.

46 Krasnai Z.L. (1987). Interspecific hybridization of warm water finfish. In: Tiews K. (ed.), Selection, Hybridization, and Genetic Engineering in Aquaculture, Vol 2. FAO, EIFAC and ICES, Rome, Italy and Copenhagen, Denmark, pp. 35-45.

47 Salami A.A., Fagbenro, O.A. and Sydenham, D.H.J. (1993). The production and growth of cariid catfish hybrids in concrete tanks. Israeli Journal of Aquaculture - Bamidgeh 45, 18-25.

48 Nwadukwe, F.O. (1995). Hatchery propagation of five hybrid groups by artificial hybridization of Clarias gariepinus (B) and Heterobranchus longifilis (Val.) (Clariidae) using dry, powdered carp pituitary hormone. Journal of Aquaculture in the Tropics 10, 1-11.

49 Khan H.A., Gupta S.D., Reddy P.V.G.K., Tantia M.S. and Kowtal G.V. (1990). 
Production of sterile intergeneric hybrids and their utility in aquaculture and stocking. In: Keshavanath P. and Radhakrishnan K.V. (eds.). Carp Seed Production Technology. Special Publication of the AFS No 2. Asian Fisheries Society, Mangalor, India, pp. 41-48.

50 Basavaraju, Y., Devaraj, K.V. and Ayyar, S.P. (1995). Comparative growth of reciprocal carp hybrids between Catla catla and Labeo fimbriatus. Aquaculture 129, 187-191.

51 Senhorini, J.A., Figueiredo, G.M., Fontes, N.A. and Carolsfeld, J. (1988). Larval and fry cultrue of pacu, Piaractus mesopotamicus, tambaqui, Colossoma macropomum, and their reciprocal hybrids. Boletin Tecnica CEPTA, 1, 19-30.

52 Tidwell, J.H., Webster, C.D. and Clark, J.A. (1992). Growth, feed conversion, and protein utilization of female green sunfish $\mathrm{x}$ male bluegill hybrids fed isocaloric diets with different protein levels. Progressive Fish-Culturist 54, 234-239.

53 Will, P.S., Paret, J.M. and Sheehan, R.J. (1994). Pressure induced triploidy in hybrid Lepomis. Journal of the World Aquaculture Society 25, 507-511.

54 Hulata, G. (1995). The history and current status of aquaculture genetics in Israel. Israeli Journal of Aquaculture - Bamidgeh 47, 142-154.

55 Colombo L., Barbaro A. Francescon A., Libertini A., Bortolussi M., Argenton F., Dalla Valle L., Vianell S. and Belvedere P. (1998). Towards an integration between chromosome set manipulation, intergeneric hybridization and gene transfer in marine fish culture. In: Bartley D. and Basurco B. (eds.). Genetics and Breeding of Mediterranean Aquaculture Species. Cahiers - Options Méditerranéennes Vol. 34. CIHEAM Zaragoza, Spain, pp. 77-122.

56 King, R.C., Stansfield, W.D. and Mulligan, P.K. (2006). A dictionary of genetics (7th edition). Oxford University Press, $242 \mathrm{pp}$.
57 Allen, J.S.K. and Wattendorf, R.J. (1987).

Triploid grass carp: Status and management implications. Fisheries 12, 20-24.

58 Steffens, W., Jaehnichen, H. and Fredrich, F. (1990). Possibilities of sturgeon culture in Central Europe. Aquaculture 89, 101-122.

59 Ernst D.H., Watanabe W.O., Ellington L.J., Wicklund R.I. and Olla B.L. (1991). Commercial-scale production of Florida red tilapia seed in low- and brackishsalinity tanks. Journal of the World Aquaculture Society 22, 36-44.

60 Head W.D., Zerbi A. and Watanabe W.O. (1994). Preliminary observations on the marketability of saltwater-cultured Florida red tilapia in Puerto Rico. Journal of the World Aquaculture Society 25, 432-441.

61 Wohlfarth, G.W. (1994). The unexploited potential of tilapia hybrids in aquaculture. Aquaculture and Fisheries Management 25, 781-788.

62 Avise, J.C. and van den Avyle, M.J. (1984). Genetic analysis of reproduction of hybrid white bass $\mathrm{x}$ striped bass in the Savannah River. Transactions of the American Fisheries Society 113, 563-570.

63 Scheerer, P.D. and Thorgaard, G.H. (1983). Increased survival in salmonid hybrids in induced triploidy. Canadian Journal of Fisheries and Aquatic Sciences 40, 2040-2044.

64 Rosenstein S. and Hulata G. (1994). Sex reversal in the genus Oreochromis: Optimization of feminization protocol. Aquaculture and Fisheries Management 25, 329-339.

65 Lahav M. and Lahav E. (1990). The development of all-male tilapia hybrids in Nir David. Israeli Journal of Aquaculture - Bamidgeh 42, 58-61.

66 Verdegem, M.C.J., Hilbrands, A.D. and Boon, J.H. (1997). Influence of salinity and dietary composition on blood parameter values of hybrid red tilapia, Oreochromis niloticus $x$ O. mossambicus. Aquaculture Research 28, 453-459.

67 Wolters, W.R. and DeMay, R. (1996). Production characteristics of striped bass $\mathrm{x}$ 
white bass and striped bass $\mathrm{x}$ yellow bass hybrids. Journal of the World Aquaculture Society 27, 202-207.

68 Bhikajee, M., 1997. Mariculture of the Red Tilapia in Enclosed Bays and in Cages: the Mauritian Experience. In: Fitzsimmons, K. (ed.). Tilapia Aquaculture. Northeast Regional Agricultural Engineering Services 106, Volume 2, New York, pp: 595-599.

69 Koren A., Pruginin Y. and Hulata G. (1994). Evaluation of some red tilapia strains for aquaculture. Israeli Journal of Aquaculture - Bamidgeh 46, 9-12.

70 Hussain, M.G. (1994). Genetics of body color inheritance in Thai and Egyptian red tilapia strains. Asian Fisheries Science 7, 215-224.

71 Dunham, R.A. and Argue, B.J. (1998). Seinability of channel catfish, blue catfish and other $\mathrm{F}_{1}, \mathrm{~F}_{2}, \mathrm{~F}_{3}$ and backcross hybrids in earthen ponds. Progressive Fish-Culturist 60, 214-220.

72 Brecka B.J., Kohler C.C. and Wahl D.H. (1995). Effects of dietary protein concentration on growth, survival, and body composition of muskellunge, Esox masquinongy, and tiger muskellinge, Esox masquinongy $\mathrm{x}$ E. luscius, fingerlings. Journal of the World Aquaculture Society 26, 416-425.

73 Dorson, M., Chevassus, B. and Torhy, C. (1991). Comparative susceptibility of three species of char and rainbow trout $x$ char triploid hybrids to several pathogenic salmonid viruses. Diseases of Aquatic Organisms 11, 217-224.

74 Nelson, K. and Hedgecock, D. (1980). Enzyme polymorphism and adaptive strategy in the decapod crustacea. American Naturalist 116, 238-280.

75 Noy, R., Lavie, B. and Nevo, E. (1987). The niche-width variation hypothesis revisited: genetic diversity in the marine gastropods Littorina punctata and L. neritoides. Journal of Experimental Marine Biology and Ecology 109, 109-116.

76 Lim C., Leamaster, B. and Brock, J.A. (1993). Riboflavin requirement of fingerling red hybrid tilapia grown in seawater.
Journal of the World Aquaculture Society 24, 451-458.

77 Snucins, E.J. (1993). Relative survival of hatchery-reared lake trout, brook trout and $\mathrm{F}_{1}$ splake stocked in low-pH lakes. North American Journal of Fisheries Management 12, 460-464.

78 Ihssen, P.E., Powell, M.J. and Miller, M. (1982). Survival and growth of matched plantings of lake trout (Salvelinus mamaycush), brook trout (S. fontinalis), and lake $x$ brook $F_{1}$ splake hybrids and backcrosses in northeastern Ontario lakes. Ontario Ministry of Natural Resources, Ontario Fisheries Technical Report Series 6, Toronto, Canada.

79 Wilkins, N.P., Gosling, E., Curatolo, A., Linnane, A., Jordan, C. and Courtney, H.P. (1995). Fluctuating asymmetry in Atlantic salmon, European trout and their hybrids, including triploids. Aquaculture 137, 77-85.

80 Grey, A.K., Evans, M.A. and Thorgaard G.H. (1993). Viability and development of diploid and triploid salmon hybrids. Aquaculture 112, 125-142.

81 Galbreath, P.F. and Thorgaard, G.H. (1995). Sexual maturation and fertility of diploid and triploid Atlantic salmon $\mathrm{x}$ brown trout hybrids. Aquaculture 137, 299-312.

82 Seeb, J.E., Thorgaard, G.H. and Tynan, T. (1993). Triploid hybrids between chum salmon female $\mathrm{x}$ chinook salmon male have early sea-water tolerance. Aquaculture 117, $37-45$.

83 Glamuzina, B., Kozul, V., Tutman, P. and Skaramuc, B. (1999). Hybridization of Mediterranean groupers: Epinephelus marginatus $\mathrm{x}$ E. aeneus and early development. Aquaculture Research 30, 625-628.

84 James C.M., Al-Thobaiti S.A., Rasem B.M. and Carlos M.H. (1999). Potential of grouper hybrid (Epinephelus fuscoguttatus $x$ E. polyphekadian) for aquaculture. Naga 22, 19-23.

85 Gorshkova, G., Gorshkova, S., Gordin, H. and Knibb, W. (1996). Karyological studies in hybrids of Beluga, Huso huso (L.) and the Russian Acipenser guldenstati. Israeli Journal of Aquaculture-Bamidgeh 48, 35-39. 
86 Kim, D.S., Jo, J.Y. and Lee, T.Y. (1994). Induction of triploidy in mud loach (Misgumus mizofepis) and its effect on gonad development and growth. Aquaculture 120, 263-270.

87 Kim D.S., Nam Y.K. and Park I.S. (1995). Survival and kayological analysis of reciprocal diploid and trploid hybrids between mud loach (Misgurnus mizolepis) and cyrinid loach (Misgurnus anguillicaudatus). Aquaculture 135, 257-265.

88 Rahman, M.A., Bhadra, A., Begum, N., Islam, M.S. and Hussain, M.G. (1995). Production of hybrid vigor through cross breeding between Clarias batrachus Lin. and Clarias gariepinus Bur. Aquaculture 138, 125-130.

89 Khan, M.M.R., Mollah, M.F.A. and Ahmed, G.U. (2000). Mass production of hybrid magur and its culture potential in Bangladesh. Aquaculture Research 31, 467-472.

90 Pongthana, N. (2001). Aquaculture Genetics Research in Thailand. In: Gupta, M.V. and B.O. Acosta (eds.). Fish genetics research in member countries and institutions of the International Network on Genetics in Aquaculture. ICLARM Conference Proceedings, 64, 77-89.

91 Padhi, B.K. and Mandal, R.K. (1997). Inadvertent hybridization in a carp hatchery as detected by nuclear DNA RFLP. Journal of Fish Biology 50, 906-909.

92 Hussain, M.G. and Mazid, M.A (2001). Genetic Improvement and Conservation of Carp Species in Bangladesh. Bangladesh Fisheries Research Institute, Bangladesh, Pages: 74.

93 FAO (2003). Fishstat plus, Version 2.30. Food and Agriculture Organization of the United Nations, Rome, Italy.
94 Mia, M.Y., Taggart, J.B., Gilmour, A., Topan, E., Das, K. et al. (2005). Detection of hybridization between Chinese carp species (Hypophthalmichthys molitrix and Aristichthys nobilis) in hatchery broodstock in Bangladesh, using DNA microsatellite loci. Aquaculture 247, 267-273.

95 Mair, G.C. (1999). Genetics of broodstock management: Basic principles and practices. A.A.R.M. Newsletter 4, 4-6.

96 Bartley, D.M., Gall, G.A.E. and Bentley, B. (1990). Biochemical genetic detection of natural and artificial hybridization of chinook and coho salmon in northern California. Transactions American Fisheries Society 119, 431-437.

97 Pullin, R.S.V. (1988). Tilapia Genetic Resources for Aquaculture. International Center for Living Aquatic Resources Management, Manila, Philippines, 108 pp.

98 Rahman, M.A. and Uehara, T. (2003). $F_{1}$ and $F_{2}$ backcrosses in the hybrids between two unnamed genetically distinct species of Tropical sea urchins Echinometra sp. A and Echinometra sp. C. Pakistan Journal of Biological Sciences 6(13), 1163-1175.

99 Rahman, M.A. and Uehara, T. (2004). Interspecific hybridization and backcrosses between two sibling species of Pacific sea urchins (Genus Echinometra) on Okinawan intertidal reefs. Zoological Studies 43, 93-111.

100 Rahman, M.A., Uehara, T., Arshad, A. Yusoff, F.M. and Shamsudin, M.N. (2012). Absence of postzygotic isolating mechanisms: Evidence from experimental hybridization between two species of tropical sea urchins. Journal of Zhejiang University-SCIENCE B (Biomed \& Biotechnol) 13(10), 797-810.

101 Arnold, M.L. (1997). Natural Hybridization and Evolution. Oxford University Press, New York, USA. 